\title{
Filosofia, ética e política de origem africana egípcia
}

\author{
Philosophy, ethics and politics of Egyptian African origin
}

Marcelo José Derzi Moraes*

Resumo: Esse texto procura desmistificar a imagem acerca do Egito Antigo constituída a partir de um racismo epistemológico por filósofos e egiptólogos europeus. Faremos uma releitura de autores antigos e contemporâneos a fim de demonstrar que o Egito africano sofrera um epistemicídio, tendo suas produções filosóficas, políticas e éticas, obliteradas por uma mentalidade racista que negava qualquer tipo de produção intelectual do povo negro africano.

Palavras-chave: Filosofia egípcia; Epistemicídio; Ética africana

\begin{abstract}
This text seeks to demystify the image about Ancient Egypt constituted from an epistemological racism by European philosophers and Egyptologists. We will re-read ancient and contemporary authors in order to demonstrate that African Egypt has suffered an epistemicide, having its philosophical, political and ethical productions, obliterated by a racist mentality that denied any kind of intellectual production of the black African people.
\end{abstract}

Keywords: Egyptian Philosophy; Epistemicide; African ethics

Uma das grandes metáforas do Ocidente é a metáfora da luz, podemos pensar, então, a história da filosofia como uma história da luz, mas também, da violência da luz. Contudo, podemos entender que negar a luz, seja ela um brilho próprio ou um brilho refletido, pode ser caracterizado por uma violência da luz. Enquanto, no outro lado do mediterrâneo, a África representaria a escuridão, um lugar sem luz. Destacamos esse cenário da luz para mostrar que a filosofia ocidental deixou de lançar ou apagou a luz no que se refere à África e ao Egito Antigo. Assim, o que foi uma violência da luz foi também um epistemicídio, constituído por um racismo epistemológico. Para Ramose, "eles fizeram isto cometendo epistemicídio, ou seja, o assassinato das maneiras de conhecer e agir dos povos africanos conquistados”. ${ }^{1}$

Se só havia escuridão antes do século das luzes na Grécia, desde os gregos, a metáfora da luz, da resolução da luz, do brilho, do ouro, do sol, sempre comandou a história da filosofia, sendo a filosofia ou a razão o grande elemento iluminador, pois, como

\footnotetext{
* Doutor em Filosofia. Professor de Filosofia da Educação da UERJ/FFP. Coordenador do projeto Ressonâncias Descoloniais em Filosofia e Educação. E-mail: marcelojdmoraes@hotmail.com

${ }^{1}$ RAMOSE, Sobre a Legitimidade e o Estudo da Filosofia Africana, p. 9.
} 
diz Descartes (1985), a razão, ou seja, o espírito é único, tal como o sol que tudo ilumina; o mesmo sol que para Platão ${ }^{2}$, se assemelha à ideia do Bem e a Luz à da verdade. Reconhecer que o Sol proporciona às coisas visíveis, não só, segundo julgo, a faculdade de serem vistas, mas também sua gênese, crescimento, sem que ele seja ele mesmo a gênese.

Esses autores não perceberam que a violência dessa luz também ofusca. Para Cheikh Anta Diop, a luz é a imagem do domínio patriarcal, centralizado no falo, promovendo, tal como um farol, uma luz a partir de seu centro, que, de forma violenta, ofusca e reprime o feminino, rebaixando-o às trevas, às profundezas, onde apenas a força fálica da luz conseguiria adentrar, sendo o patriarcado "superior ao matriarcado: é antes de mais espiritualidade, luz, razão, delicadeza. (...) o matriarcado estaria ligado às profundezas cavernosas da terra, à noite, à luz, à matéria”. ${ }^{3}$ Entretanto, se desfocarmos da luz vinda da Europa, que ofusca os nossos olhos e nossa mente, veremos que o Ocidente não surgira de uma noite para o dia na Grécia do século V antes dessa era. O Ocidente fora constituído a partir de suas relações com o Egito ou Kemet - terra negra ou país de homens negros, kmt (negros; preto-carvão), país e região africana de povo preto, como nos explica Diop $^{4}$. Possuidores de uma história que teve início por volta de 12.000 a.C, os kemetianos faziam filosofia, ciência, medicina e história, bem antes que Tales, Pitágoras, Isócrates, Platão, Aristóteles, como fora adiantado por alguns desses filósofos que viajavam ao Egito ou, segundo historiadores, tais como Diógenes Laêrtios e Heródoto. Diante disso, a fala de Roger Garaudy é pertinente nesse momento: “o que se convencionou chamar de Ocidente teve origem na Mesopotâmia e no Egito, isto é, na Ásia e na África. (...) O Egito inspirou fortemente toda a civilização grega”. ${ }^{5}$

Assim, podemos pensar essa metáfora da luz a partir do Egito, da figura do sol como deus, do faraó como o deus-sol, antes mesmo de falarmos da saída da caverna, do abandono das trevas, do rei-sol do absolutismo, das luzes da razão, do Estado absoluto e da democracia como o grande farol da humanidade. Deste modo, contra a interpretação dominante acerca do Egito africano, nossa ideia é conjurar as leituras tradicionais, que não passam de interpretações da violência, pois atribuem uma identidade fixa, engessada, conservadora e imóvel ao Egito. As leituras tradicionais insistem em uma imagem do Egito perverso, despótico, em que o faraó escravizava o povo, logo não havia experimentado a liberdade. Portanto, por serem privados da liberdade, também não poderiam possuir de um pensamento filosófico devido à incapacidade de abstração, uma vez que seria uma

\footnotetext{
2 PLATÃO, República, 509ab.

${ }^{3}$ DIOP, A unidade cultural da África Negra. Esferas do patriarcado e do matriarcado na antiguidade clássica, p. 14.

${ }^{4}$ Em 1974, no Le Colloque Mondial du Caire sur l'Origine du peuplement de l'Egypte ancienne, Diop teve o reconhecimento de dezenas de egiptólogos e estudiosos do mundo inteiro sobre o seu trabalho acerca da negritude dos egípcios.
}

${ }^{5}$ GARAUDY, O Ocidente é um acidente, p. 6-8. 
sociedade completamente submissa, religiosa, teocrática, não conseguindo alcançar um pensamento racional desprovido de mitos.

Para combater um tipo de violência ou de racismo geográfico, Jean Vercoutter, fazendo valer todo o esforço de Cheikh Anta Diop e Théophile Obenga, reforça que "a civilização egípcia não foi importada para o Egito, ela nasceu no próprio vale, é essencialmente nílica e africana”, a fim de contrapor a tentativa de origem hegeliana de retirar o Egito da África.

A principal característica dos negros é que sua consciência ainda não atingiu a intuição de qualquer objetividade fixa, como Deus, como leis, pelas quais o homem se encontraria com a própria vontade, e onde ele teria uma ideia geral de sua essência. (...) O negro representa, como já foi dito o homem natural, selvagem e indomável. Neles, nada evoca a ideia do caráter humano. (...) A carência de valor dos homens chega a ser inacreditável. A tirania não é considerada uma injustiça (...) Com isso deixamos a África (...) O Egito será abordado como transição do espírito humano do Oriente para o Ocidente, mas ele não pertence ao espírito africano. Na verdade, o que entendemos por África é algo fechado sem história, que ainda está envolto no espírito natural'.

Nosso interesse em reforçar uma outra história do Egito é a de considerar as palavras de Diop, em pensar um espírito africano múltiplo, para seguir uma linha diferente da proposta pela história da filosofia de Hegel, que tentou a todo custo, retirar o Egito da África, uma vez que ele se "surpreende encontrar entre eles, bem em meio à estupidez africana, uma razão refletida, uma nítida organização em todas as instituições e impressionantes obras-de-arte" 8 .

Para nós, o retorno ao Egito em todos os campos é a condição necessária para reconciliar as civilizações africanas com a história, para poder construir um corpo de ciências humanas modernas, para renovar a cultura africana. Longe de ser um deleite sobre o passado, olhar para o Egito Antigo é a melhor maneira de conceber e construir nosso futuro cultural. $\mathrm{O}$ Egito representará, na cultura africana redesenhada e renovada, o mesmo papel que as antiguidades greco-latinas na cultura ocidental ${ }^{9}$.

\footnotetext{
${ }^{6}$ VERCOUTTER, O Egito Antigo, p. 09.

${ }^{7}$ HEGEL, Filosofia da História, p. 83-88.

${ }^{8}$ Ibidem, p. 172.

${ }^{9}$ DIOP, Civilisation ou Barbarie, p. 12.
} 
Ainda contra Hegel, que, em todo seu racismo, nega a possibilidade de um espírito africano, mas que reconhece o espírito egípcio, apesar de considerar um espírito fraco e não possuidor de uma beleza, podemos encontrar no Egito, toda uma cultura (paideia) egípcia, apesar do etnocentrismo de Werner Jaeger, que afirma categoricamente que "não havia cultura antes dos gregos” ${ }^{10}$. Porém, veremos que inúmeros filósofos, políticos e poetas gregos, viajavam ao Egito com o intuito de aprender, de conhecer. Segundo historiadores e filósofos gregos, Sólon, que fora um grande político e poeta, viajou diversas vezes ao Egito, e, de acordo com Heródoto, teria ido ao Egito a fim de fortalecer relações de cunho comercial e conhecer mais sobre as legislações do Egito, como foi o caso da lei que obrigava a declaração anual dos rendimentos, e que Sólon "adotou em Atenas essa lei, ainda hoje em vigor naquela cidade, por ser muito sensata e justa" ${ }^{\text {. }}$.

Esse aprendizado e curiosidade de Sólon são reforçados por Platão, que explica que Sólon, "quanto às leis, observa-as à luz das daqui, pois encontrarás cá muitos exemplos de leis que vigoravam naquele tempo entre vós"12. Essa mesma narrativa é encontrada em Aristóteles, que conta que Sólon viajou ao Egito buscando estabelecer relações comerciais e conhecer o país ${ }^{13}$. Plutarco, por sua vez, comenta que Sólon ao viajar ao Egito, "gastó cierto tiempo en filosofar con Psenofis de Heliópolis, y con Sonquis de Sais, los más sabios e instruidos de aquellos sacerdotes" ${ }^{14}$. Destacamos a vida de Sólon, porque ao retornar a Atenas, há o surgimento da democracia e da filosofia. Em outras palavras, Sólon vivera mais de dez anos fora de Atenas, buscando aprimorar e conhecer novas leis e culturas, e ao regressar, promove uma transformação social. Cabendo destacar que, segundo Aristide Théodoridès, no período de 664 a.C, "os gregos entraram em contato com a cultura do Vale do Nilo, e, segundo a tradição, foi no Egito, nas cidades do Delta, que adquiriram as ideias de liberdade e de igualdade democrática” ${ }^{15}$. Além disso, para Abu Bakr, os egípcios já possuíam uma compreensão dos valores democráticos em diferentes planos, tais como o divino, o social e o religioso. Para ele, os kemetianos sem dúvida consideravam a democracia como a igualdade de todos "os homens perante os deuses por um lado, e perante os governantes por outro" ${ }^{16}$.

No Primeiro Período Intermediário podemos encontrar a democratização da imortalidade da alma, uma vez que, anteriormente, estava reservada apenas ao faraó e aos sacerdotes. Esse fenômeno, que se deu devido a uma certa crise política, descentralizando o poder da mão do faraó e da elite sacerdotal, possibilitou o acesso aos Textos do sarcófago,

\footnotetext{
${ }^{10}$ JAEGER, Paideia, p. 5.

${ }^{11}$ HERÓDOTO, História, p. 219.

12 PLATÃo, Timeu-Crítias, p. 86.

${ }^{13}$ ARISTÓTELES, A constituição de Atenas, p. 50.

${ }^{14}$ PLUTARCO, Vidas Paralelas, p. 219.

${ }^{15}$ HARRIS, O legado do Egito, p. 329.

${ }^{16}$ BAKR, O Egito faraônico, p. 114.
} 
todos podiam buscar o seu caminho a uma vida no além, sem depender da liberação do monarca.

\begin{abstract}
Observe que os termos "democratização" ou "desmotização" são usados por especialistas, para lidar com a divulgação de textos e crenças funerárias do rei para alcançar todas as pessoas, especialmente no que se refere à passagem dos textos das pirâmides aos textos sarcófagos. Essas palavras referem-se à ideia de uma exclusividade real em oposição aos costumes funerários populares, como se depois de um enfraquecimento do poder real o privado tivesse tomado o destino real post mort. ${ }^{17}$
\end{abstract}

Kemet é datada de mais de quatro mil anos antes da nossa era, isso se nos situarmos no período político, que está situado entre 4000 até 300 a.C, mas que, segundo Jean Vercoutter: “A civilização egípcia data de mais de cinco mil anos" ${ }^{18}$. Nesse sentido, apenas uma imaginação limitadora poderia acreditar que uma sociedade permanecesse imodificável por tantos milénios, não sofrendo nenhuma modificação, parada no tempo, imóvel, em um único e só mesmo lugar. É por esta mesma razão, que Platão compreendeu o uso da escrita e dos arquivos por parte dos kemetianos, fato que o fez reconhecer os gregos como crianças pertos dos egípcios, uma vez que "perdestes a memória, pois morreram os sobreviventes sem terem legado o seu depoimento à escrita durante muitas gerações” 19 .

Muito se fala e se reproduz do Egito enquanto um Estado, representado na figura do faraó. Esse é um dos principais preconceitos e ignorância no que tange o Egito, uma vez que o Egito teve mais de trezentos faraós. Sendo assim, seria impossível que todos fossem iguais. Além disso, pouco se explora dos períodos de insegurança política por parte do Estado, períodos nos quais o rei perdia a concentração de poder que era disseminado nas mãos de pessoas, de classes e de grupos sociais que acabavam por administrar e influenciar nos caminhos do Estado, corroborando com “a legitimação do poder destas elites”"20.

O Egito, tradicionalmente, enquanto unidade, foi dividido em quatro fases, o Antigo Império ou Reino Antigo (2685-2160); o Médio Império ou Reino Médio (2065-1785); Reino Novo ou Novo Império (1580-1200); Época Tardia ou Período Superior (1200 até a invasão grega, 300 $)^{21}$ - possuindo algo em torno de trinta dinastias. Entre cada uma dessas fases,

\footnotetext{
${ }^{17}$ GAMA-ROLAND, L'existence ou pas d'une “démocratisation” ou "demotisation” du post mortem: l'étude des chaoabtis du Nouvel Empire, p. 126.

18 VERCOUTTER, O Egito Antigo, p. 07.

${ }^{19}$ PLATÃO, Timeu-Crítias, p. 23.

${ }^{20} \mathrm{JOÃO}$ Implicações econômicas dos templos egípcios e a constituição de poderes locais: um estudo sobre o Reino Antigo, p. 60.

${ }^{21}$ VERCOUTTER, O Egito Antigo, p. 34.
} 
havia momentos pouco explorados, denominados períodos intermediários, "épocas de anarquia, descentralização do poder, declínio econômico, ásperas lutas sociais e políticas e mesmo fases de domínio estrangeiro" ${ }^{22}$. Os períodos intermediários são nomeados como Primeiro Período Intermediário (2400-2065), o Segundo Período Intermediário (1785-1580) e o Terceiro Período Intermediário (ou o Período de Decadência) (1200-333), o final deste último período, foi marcado por visitas e invasões gregas ao Egito, por parte de mercenários, políticos, filósofos, poetas, comerciantes, até a invasão de Alexandre em 333 a. $\mathrm{C}^{23}$.

Esses períodos de fases de transição, que no seu total passam de mil anos, possuem uma característica que nos interessa aqui para desmistificar os grandes mitos preconceituosos e etnocêntrico, fundados em um racismo epistemológico, a saber, o despotismo asiático, a escravidão, a subordinação social, a alienação política, uma imagem política cristalizada, o patriarcalismo, entre tantos outros preconceitos. Devemos destacar nesses períodos, sobretudo, a descentralização do poder do rei, ascensões sociais, mudanças de classes sociais, a perda de controle e de poder sobre as pessoas e o rumo do país, marcados por guerras civis, greves e revoluções populares, trazendo "a fragmentação do poder central" 24 . Segundo Abu Bakr, depois de uma revolução que ocorrera no Primeiro Período Intermediário, novos valores acabaram por surgir na vida do Egito Antigo. Nesse período, surgiu um valor maior sobre o homem comum cuja autonomia era mais valorizada. No papiro Protestos de um Camponês Eloquente, texto datado do período do Reino Médio, entre 2065 até 1785 a.C, é possível encontrar uma reflexão ética acerca da justiça. Para autores como, Rashid El-Nadoury e J. Vercoutter, esse foi o primeiro texto direcionado à revolução e à democracia ${ }^{25}$. Assim, lemos: "não roubes as coisas de um pobre, um homem humilde que sabes quem é" O ar do pobre são seus pertences, quem os toma tapa seu nariz. (...) Quem combate a mentira favorece a verdade”26.

O Segundo Período Intermediário durou mais de duzentos anos, caracterizado pelas eleições de reis ${ }^{27}$. Ainda neste período, a subida ao poder provoca uma mudança de classe social, como é o caso de Ahmés, filho de Ibana, devido às suas conquistas em épocas de guerra, possibilitando, "a ascensão social e a legitimação de sua posição social perante os demais integrantes da sociedade relaciona-se diretamente com sua formação militar específica” ${ }^{28}$.

\footnotetext{
${ }^{22}$ CARDOSO, O Egito Antigo, p. 03.

${ }^{23}$ VERCOUTTER, O Egito Antigo, p. 35.

${ }^{24}$ Ibidem, p. 62.

${ }^{25}$ El-NADOURY; VERCOUTTER, O legado do Egito faraônico, p. 154.

${ }^{26}$ ARAÚJO, Pobres faraós divinos, p. 238.

${ }^{27}$ VERCOUTTER, O Egito Antigo, p. 69.

${ }^{28}$ ARRAIS, Hierarquia e Mobilidade Social no Egito do Reino Novo, p. 101.
} 
No Antigo Império, por volta da V dinastia, no tratado ético do filósofo Ptah-hotep, localizamos que a ascensão social já era possível, pois em seus ensinamentos, o filósofo kemetiano ressalta a necessidade ética da pessoa que ascende socialmente. Diante disso, seria possível compreender que "havia uma certa igualdade de oportunidade, ao menos para o egípcio" 29 . Por isso, podemos encontrar em Ptah-hotep a instrução que diz: "se fores grandes após teres sido um humilde, se enriqueceste após teres sido pobre numa cidade que conheces e que sabe de teu passado, não te exibas em tua riqueza” ${ }^{30}$.

No Novo Império encontramos uma faraó mulher, a rainha Hat-shepsut ${ }^{31}$, que se destacava "de forma espetacular no plano artístico"32. Existem pelo menos mais três mulheres, Nitócris, Sebeknefru e Tauosré, que, segundo Yoyotte, "passaram à posteridade como usurpadoras. Eram pródigas as honras demonstradas à mãe, esposas e filhas do rei" 33 . Heródoto destaca que Nictóris: "entre os trezentos e trinta reis que governaram o Egito depois de Menes figuram dezoito Etíopes e uma mulher natural do país. (...) A mulher chamava-se Nitócris, como a rainha da Babilônia"34.

Para Cheikh Anta Diop (2014) e Nah Dove (2002; 2017), o Egito era marcado por uma origem matriarcal ou maternocentralizada que se reproduzia na composição familiar e estatal das sociedades africanas. Cabe lembrar, em Tebas, “A mãe das cidades”, havia um núcleo de sacerdotisas conhecidas como Adoradoras Divinas de Amon. O culto à mulher era tão forte, que o respeito e a dedicação à mulher estavam presentes nos ensinamentos de Ptah-hotep: "alegra o seu coração enquanto viveres, ela é um campo fértil para seu senhor" 35 . Lembrando que "no berço civilizatório 'meridional', a mulher goza de uma posição de destaque na comunidade, sendo ela emancipada da vida doméstica”. ${ }^{36}$

Percebemos, inclusive, ascensões de cargo que escapavam à centralização da família real, como são os casos de Ramsés I, de Herihor e de Horemheb ${ }^{37}$, situações políticas que se diferenciam do Reino Antigo, pois o rei não possuía uma concentração de poder, estando sempre sob ameaças internas e externas. Assim, era preciso uma inteligência prática para manter as relações políticas: "há casos comprovados, embora esporádicos, de renovação dos quadros aristocráticos com pessoas de origem humilde, podendo em especial a carreira de escriba ou a militar abrir caminho à ascensão social”38.

\footnotetext{
${ }^{29}$ CARREIRA, Filosofia Antes dos Gregos, p. 169.

${ }^{30}$ PTAH-HOTEP, Ensinamentos de Ptahhotep, p. 255.

${ }^{31}$ ARAÚJO, Pobres faraós divinos, 1996.

32 VERCOUTTER, O Egito Antigo, p. 77.

33 YOYOTTE, O Egito faraônico: sociedade, economia e cultura, p. 82.

${ }^{34}$ HERÓdOTO, História, p. 178.

35 PTAH-HOTEP, Ensinamentos de Ptahhotep, p. 252.

${ }^{36}$ MOORE, Racismo e Sociedade, p. 120.

37 VERCOUTTER, O Egito Antigo, p. 84-96.

${ }^{38}$ CARDOSO, O Egito Antigo, p. 15.
} 
Ressaltamos esses pontos para mostrar que a imagem cristalizada de um Egito único, marcado pelo terror despótico, constitui um dos milhares de racismos promovidos pelo Ocidente. Sendo assim, percebemos que o poder, por vezes, foi disseminado pelos grupos sociais ${ }^{39}$, que o acesso ao poder não foi sempre divino. Assim, apresentar esse panorama político é de extrema importância para compreendermos alguns aspectos de como a filosofia era importante para o egípcio; uma vez que seria preciso um tipo de mentalidade para poder lidar com as mudanças e com os cenários políticos vigentes. Sendo assim, uma formação político-filosófica, era de extrema importância, visto que em assembleias, reuniões entre grupos, entre as classes, entre as elites econômicas e sacerdotais, nos encontros com a realeza, quando se tinha que decidir a administração "pública” e o futuro do Estado, era preciso uma boa formação intelectual, que considerava, sobretudo, o conhecimento de história, de cultura, a capacidade de reflexão do real, uma apreensão mais aguçada dos fatos. Até pelo motivo de que o poder não era garantido só pelas riquezas e propriedades, mas na capacidade de se destacar em debates, em assembleias, tribunais e reuniões de menor instância ${ }^{40}$. Assim, pensamos em termos de classe, pois o conceito clássico de casta, ontologicamente não permitiria a mudança no contexto social.

Nestes escritos primordiais pode-se entrever uma distinção básica da

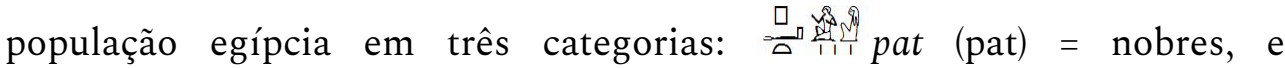
R. Hent (henememet) = povo de Heliópolis ou "povo solar" O 440 的 (Sonnenvolk) rxyt (rehety) = povo, subordinados, que podem ser interpretados respectivamente como nobreza, nobreza menor e as pessoas comuns ou plebe ${ }^{41}$.

É bom destacar que, em mais de três mil anos, o Egito fora dividido em dois reinos (sul e norte), às vezes, em três reinos (sul, centro e norte), assim, sendo regido por rei, possuindo, às vezes, duas dinastias ao mesmo tempo. A extensão do Egito era tão considerável, que havia, pelo menos, 38 spat, ou seja, nomos, que são como regiões administrativas ou distritos, onde havia uma capital e um templo religioso próprio, sendo regidos por um nomarca, uma espécie de governador ou administrador, que, mesmo estando numa escala abaixo do faraó, havia períodos em que possuíam uma maior capacidade autônoma de decisão. Sendo que, "a forma como se apresentam a divisão e organização do território egípcio reforça a tese do caráter local de poder baseado nas

\footnotetext{
${ }^{39}$ JOÃO, Implicações econômicas dos templos egípcios e a constituição de poderes locais: um estudo sobre o Reino Antigo, p. 23-24.

${ }^{40}$ CARDOSO, O Egito Antigo, p. 20.

${ }^{41}$ ARRAIS, Hierarquia e Mobilidade Social no Egito do Reino Novo, p. 93.
} 
comunidades aldeãs egípcias anteriores a unificação do Estado, sendo este, provavelmente, resultante de conflitos" 42 .

A capacidade de uma boa formação, que vai passar pela capacidade de falar bem, de uma boa oratória, não se dá apenas no campo político, mas também no direito. A questão do direito, inclusive de um direito laico, é fundamental para se destacar, para não criar-se o mito de um direito divino, religioso ou de acordo com a vontade do faraó. Nesse sentido, se estamos falando de direito, é preciso considerar o âmbito privado e público. Há um momento, por exemplo, em que é preciso debater a respeito do direito à propriedade, uma vez que as terras não seriam em absoluto do rei.

Para Aristide Théodorides, no Antigo Império, o direito era secular, não estando preso à religião, que se destacava enquanto uma sofisticada instituição, sendo que "todo o tratado cotidiano da existência no vale do Nilo é regulado pelo direito" ${ }^{43}$. Nesse sentido, pode se compreender quando alguns autores afirmam que não havia uma quantidade tão enorme de escravos ${ }^{44}$, até porque, segundo alguns atores, a obediência fora confundida com a escravidão, cuja "segurança promovida por um governo central paternalista com amplos silos para alimentar os trabalhadores" ${ }^{45}$. Portanto, todos os trabalhadores eram possuidores de direitos, lembrando "quem trabalhava na terra não eram servos de nenhum senhor. Eram comunidades livres que sofriam uma espécie de tributação coletiva por parte das elites dirigentes" ${ }^{46}$. Sendo "a afirmação - comum em obras antigas - de ser o rei o único proprietário das terras egípcias não é exata” ${ }^{47}$.

Segundo alguns autores, essas instabilidades, essas modificações políticas e sociais, acabaram por promover muitas mudanças em relação ao egípcio, principalmente, no aspecto individual. Essa modificação permite falarmos em termos de individualidade ou de grupos sociais, apagando aquela imagem de povo submisso ao rei, uma vez que enfraquecida a figura do faraó, abriu-se espaço para a constituição de uma nova forma de organização coletiva, ao mesmo tempo em que houve o reforço na identidade e individualidade de determinados homens ${ }^{48}$.

Como a mudança é inevitável em quase quatro mil anos de história, quando havia essas situações de crises, de revoluções, de mudanças de valores, novas perspectivas e

\footnotetext{
42 ARRAIS, Isis, o trono do Egito: análise das representações da deusa e do poder régio no Egito do Reino Novo, p. 61-62.

${ }^{43}$ HARRIS, O legado do Egito, p. 330.

${ }^{44}$ Ibidem, p. 318.

${ }^{45}$ CASTANEDA, apud JOÃO, Implicações econômicas dos templos egípcios e a constituição de poderes locais: um estudo sobre o Reino Antigo, p. 31.

${ }^{46}$ DOBERSTEIN, O Egito Antigo, p. 126.

${ }^{47}$ CARDOSO, O Egito Antigo, p. 14.

48 JOÃO, Implicações econômicas dos templos egípcios e a constituição de poderes locais: um estudo sobre o Reino Antigo, p. 60.
} 
modos de ser, em momentos como os das descentralizações de poder da comunidade faraônica, o indivíduo que estava ligado diretamente ao faraó, seja por meio da religião ou mesmo de questões de âmbito econômico, passa se compreender como um indivíduo autocentrado, voltado para si mesmo para se compreender como sujeito, como homopolítico. Entretanto, apesar de usarmos conceitos da modernidade -sujeito; indivíduo - europeia para designar o egípcio ou o kemetiano, seria interessante saber que o kemetiano possuía uma noção do seu lugar no mundo, mas também, na niut (pólis; cidade), que era formada por seu $B a$ (Alma) e o seu ser social. Essa compreensão de existência no mundo nos remete ao que Isócrates disse em relação ao egípcio, que inventara a filosofia e a medicina para viver bem, com plenitude em sociedade, com corpo e alma saudáveis ${ }^{49}$. A respeito da individualidade do kemetiano, é interessante sempre recorrer às autobiografias e biografias dos textos clássicos, como são os casos das autobiografias de Weni e Ankhtif. Nesses dois casos é possível ver a transformação de uma mentalidade e de um modo ser em termos de existência no que diz respeito à relação do indivíduo com o mundo egípcio ${ }^{50}$.

Esses exemplos, que se concretizavam, se efetivavam, principalmente, nos períodos intermediários, demarcam a disseminação do poder e a possibilidade da participação ainda maior de todos os grupos sociais. Sendo assim, podemos encontrar funcionários, coletores de impostos, policiais, cortesãos, tesoureiros, sacerdotes, militares, juízes, vizires, escribas, nomarcas, funcionários que ocupam um lugar mais baixo na hierarquia social, tendo uma participação maior nos espaços estatais, compondo a formação do Estado, cabendo salientar, que muitas vezes os sacerdotes decidiam quem deveria assumir o reinado ${ }^{51}$. Assim, "nas fases em que o poder central enfraquecia seu controle, valores competitivos ganhavam vantagem sobre os valores que favoreciam a integração" ${ }^{52}$.

Admoestações de Ipu-ur, datado de 1300 a.C, possivelmente se refere ao Segundo Período Intermediário (1785-1580). O texto trata da insatisfação de um homem da realeza ou da elite com as mudanças ocorridas após uma revolução social, que invertera valores e papéis na sociedade egípcia, possibilitando que outras pessoas de classes inferiores ocupassem espaços políticos e religiosos que anteriormente eram reservados à elite e à realeza, "em verdade os pobres passaram a exibir luxo e o que não podia ter sandálias possui riqueza. Em verdade os criados estão vorazes e o poderoso não mais compartilha de alegria com sua gente. (...) Em verdade os poderosos passam fome e necessidade, os servos são servidos” ${ }^{53}$.

\footnotetext{
${ }^{49}$ BRISSON, Leituras de Platão, 2003.

${ }^{50} \mathrm{JOÃO}$, Implicações econômicas dos templos egípcios e a constituição de poderes locais: um estudo sobre o Reino Antigo, 2008.

${ }^{51}$ CARDOSO, O Egito Antigo, 1992.

52 ASSMANN apud JOÃO, Implicações econômicas dos templos egípcios e a constituição de poderes locais: um estudo sobre o Reino Antigo, p. 20.

${ }^{53}$ ARAÚJO, Pobres faraós divinos, p. 177-181.
} 
Porém, as mudanças sociais provocavam uma preocupação para aqueles que precisavam administrar o Estado ou para aqueles que ocupavam um lugar de poder e que se sentiam ameaçados. Nesse sentido, uma vez que poderíamos perceber uma questão política que prima pela interpretação de um cenário público-privado, foi preciso criar novas maneiras, práticas de governar, sendo essa, portanto, uma questão de reflexão filosófica, uma vez que estavam em jogo os rumos da sociedade e o modelo ético, além, da permanência e da concentração do poder. Essa discussão é possível de ser encontrada nos textos Ensinamentos para o rei Meri-ka-Rã de aproximadamente 2100 a.C e Ensinamentos do Rei Amen-em-hat I, que em muito nos remete à Maquiavel, pois o que está em jogo é a arte de governar, considerando os ideais de bem e de justo. Portanto, nos Ensinamentos para o rei Meri-ka-Rã podemos encontrar: "não sejas mau, a benevolência é boa, faze tua lembrança durar por amor a ti. (...) Fazer justiça e terás vida longa pela terra (...) Pune com açoite e com prisão, e assim o país ficará em boa ordem" ${ }^{54}$.

Se recorrermos aos textos de Ptah-hotep e Amen-em-ope, encontraremos além de questões de cunho político, problemáticas que são do âmbito ético. Nesses dois autores, podemos perceber, por exemplo, dois momentos distintos em termos de discussões éticas. Enquanto em Ptah-hotep a obediência ao faraó e aos deuses permitiam uma vida digna, sendo, assim, um valor supremo; em Amen-em-ope a preocupação com o cuidado de si e com outrem era fundamental. Nesses dois tratados, separados por períodos distantes, está presente a importância de um modo ético de ser, de como agir, enquanto um homem virtuoso (neb qued) em Ptha-hotep ou enquanto um homem silencioso, homem sereno (geru ou geru maã) em Amen-em-ope. Nesse sentido, o caminho na busca da felicidade, está muito próximo do que Aristóteles irá defender depois de milênios, a saber, uma vida equilibrada, que, nas palavras de Aristóteles, se dá por uma vida sem exageros, que vise a um meio termo. Ao contrário do homem inflamado, o homem sereno "se conserva plácido, é como árvore que cresce no prado: floresce e duplica o que produz" ${ }^{55}$. Renato Noguera nos esclarece, "as características do geru maa circunscrevem pelo menos uma questão: a possibilidade de uma vida feliz" ${ }^{56}$.

O tratado de Amen-em-ope é um tratado ético, elemento central na filosofia, se iniciando como uma questão cara na história da filosofia: como ser feliz? ${ }^{57}$. Desta maneira, é possível perceber, nos textos de Amen-em-ope e Ptah-hotep, uma ética de viver, na qual o imperativo é do que não se deve fazer. O filósofo grego Sócrates, discípulo de Platão, irá reproduzir o mesmo ensinamento de Ptah-hotep, do perigo da vaidade do conhecimento, nos alertando de que nada sabemos, e que estamos sempre aprendendo: "Não te envaideças

\footnotetext{
${ }^{54}$ Ibidem, p. 283-285.

${ }^{55}$ AMENEMOPE, Ensinamentos de Amenemope, p. 265.

${ }^{56}$ NOGUERA, A ética da serenidade: o caminho da barca e a medida da balança na filosofia de Amenemope, p. 153.

${ }^{57}$ AMENEMOPE, Ensinamentos de Amenemope, p. 262.
} 
de teu conhecimento, toma conselho tanto do ignorante quanto do instruído, pois os limites da arte não podem ser alcançados e a destreza de nenhum artista é perfeita" 58 .

Desde Homero, é possível conhecer a grandiosidade do povo egípcio pelos gregos. Homero "dizia que todos os homens do Egito eram médicos" 59 . Seja na medicina, na medicina cirúrgica, na astronomia, na geometria, na matemática ou na política, os gregos viam nos kemetianos um exemplo, ao ponto de Pierre Henri Larcher entender o extenso trabalho produzido por Heródoto, acerca do Egito, como uma maneira "de dar aos Gregos uma ideia da forma de seu governo e de seus costumes, com uma descrição sucinta de seu país" 60 .

Pitágoras, o filósofo de Samos, que viveu quase 22 anos estudando no Egito, compreendia essa terra africana como a mãe da Grécia: "velha como o mundo, imóvel como uma múmia coberta de hieróglifos, no fundo de suas pirâmides, mas possuindo no seu túmulo o segredo dos povos, das línguas e das religiões" ${ }^{61}$. No Egito, Pitágoras pode passar a ter uma "vista do alto que permite aperceber as esferas da vida e as ciências numa ordem concêntrica; compreender a involução do espírito na matéria pela criação universal"62.

A admiração sobre os kemetianos vinham de outras terras, como da Fenícia. O príncipe de Biblos, na Fenícia, ao se referir ao egípcio Venamun: "Amon fundou todos os países, fundou-os após ter criado primeiramente o Egito. A arte veio de lá, de onde tu vens, até aqui onde eu estou, e a educação veio de lá até aqui onde eu estou”63. Enquanto, os caldeus, segundo Diodoro da Sicília, estudavam com os egípcios, se tornando especialistas na astrologia "por tê-la aprendido dos sacerdotes egípcios"64. Diante dessas declarações, podemos compreender quando François Hartog afirma que viajar ao Egito, para um grego, é voltar no tempo e aprender, pois "fazer a viagem do Egito é, para um grego, um meio de ter 'mais lembranças que se tivesse mil anos'! Encontrar a memória que ele não tem ou reencontrar a que não tem mais" ${ }^{65}$.

De acordo com alguns autores, os egípcios descobriram os papiros e possuíam modelos diversos de escritas; segundo alguns, foram eles que inventaram a escrita, como diz Platão. Porém, autores, como Jean-Pierre Vernant (2004), defendem que a escrita foi uma condição da democracia na Grécia. Ora, se a escrita fora a condição da democracia, é preciso ter cuidado ao afirmar essa tese, uma vez que os kemetianos já usavam desta técnica, mesmo que ela, tal como na Grécia, fosse restrita a um grupo não muito largo.

\footnotetext{
${ }^{58}$ PTAH-HOTEP, Ensinamentos de Ptahhotep, p. 247.

${ }^{59}$ LAÊRTIOS, Vidas e doutrinas dos filósofos ilustres, p. 87.

${ }^{60}$ HERÓDOTO, História, p. 24.

${ }^{61}$ SCHURÉ, Pitágoras, p. 45.

${ }^{62}$ Ibidem, p. 24.

${ }^{63}$ MANACORDA, História da Educação, p. 21.

${ }^{64}$ Ibidem.

${ }^{65}$ HARTOG, Memória de Ulisses: narrativas sobre a fronteira na Grécia antiga, p. 59.
} 
Para Jean Vercoutter: “a escrita é mesmo produto exclusivo da civilização egípcia e que nasceu nas margens do Nilo" ${ }^{66}$. Vernant também irá defender que o logos era fundamental para a democracia enquanto discurso, oratória. Mas, se levarmos em conta o logos egípcio, que, para Hartog, possuía uma capacidade de transformação e mudança, como, também, de conservação e ordem social, precisamos pensar esse logos em sua potência, ao contrário do que alegava Platão.

O ensino (sebayt) se dava de diversas maneiras e em todos os grupos sociais, nas per ānkh (casa da vida), nas escolas, na "casa dos escritos”, ou seja, nas bibliotecas. Os ensinamentos possuíam "um caráter universal" ${ }^{67}$, pois eram voltados para a formação do homem político homopolitico. Então, por meio de leituras ou ditados ou pela oralidade, os educadores eram quase sempre os escribas, mas também, funcionários, pais, príncipes, sacerdotes, vizires tais como Ptah-hotep, Kares, Mênfis, Hergedef, Khety, Nefeferty, Khakheper-ra-seneb, Imoteph.

O elemento primordial na formação passava pelo aprendizado da oratória, uma vez que estavam sendo formados para o campo político. Para Mario Manacorda, a arte de falar bem se refletia da necessidade de se posicionar e se defender em assembleias e em reuniões na corte. Portanto, “o falar bem é, então, conteúdo e objetivo do ensinamento. (...) pela primeira vez na história, nos encontramos perante a definição da oratória como arte política do comando"68. Portanto, se a escrita tinha como função, além de preservar a história da sociedade, auxiliar como método didático na transmissão de ensinamentos, na administração pública do país, dando um sentido político nas relações sociais; a arte da palavra, a arte de falar bem, tinha um caráter ainda mais valorizado do que a escrita. Diante disso, não tem como negar que havia um mundo egípcio, uma cultura egípcia, que poderia ser traduzido, como defende Mario Alighiero Manacorda, em Paideia. Havia um sistema de formação do indivíduo ou cidadão kemetiano, que era voltado para a relação interna e externa. Sendo assim, compreendemos uma outra concepção de política no Egito Antigo, que nos conduz a repetir a fala de Marcel Detienne que alerta que "o senso comum gosta de acreditar não somente que o político ou a política caiu do céu, um belo dia, e portanto na Atenas "clássica”, sob a forma miraculosa e autenticada da democracia" ${ }_{69}$.

Segundo Hegel e uma tradição de filósofos posteriores, uma das razões da impossibilidade de haver filosofia se dá pelo motivo da falta de liberdade, uma vez que havia um regime escravocrata que se mantinha a partir de um estado despótico. Não iremos entrar aqui no mérito de que a maior parte da população na Grécia - de $300 \mathrm{mil}$ pessoas, apenas 40 mil eram cidadãos - estava dividida em escravos, mulheres e metecos,

\footnotetext{
${ }^{66}$ VERCOUTTER, O Egito Antigo, p. 28.

${ }^{67}$ MANACORDA, História da Educação, p. 25.

${ }^{68}$ Ibidem, p. 27.

${ }^{69}$ DETIENNE, Os gregos e nós, p. 127.
} 
que seriam desprovidos de direito, uma "oligarquia escravagista”, segundo Garaudy ${ }^{70}$. Vale lembrar, que Sócrates, privado de sua liberdade, ainda fazia filosofia antes de sua morte.

Em primeiro lugar, seria importante desmistificar uma imagem cristalizada de um Egito bíblico, marcado pela escravidão, pela submissão e o terror despótico do faraó, uma vez que houve uma história de mais de 300 reinados dentro de quase quatro mil anos. Em segundo lugar, desmontar o preconceito de Hegel e sua falta de conhecimento, no que tange ao Egito. Ao explicar que "o despotismo em geral é o Estado de ausência de leis, no qual a vontade particular enquanto tal, seja a vontade do príncipe ou a de um povo (oclocracia)"71 , o filósofo alemão reforça seu desconhecimento e promove um preconceito ao dizer que o Egito era um lugar de ausência de leis onde só imperava a vontade do rei $^{72}$. Seja por falta de um desconhecimento intencional ou não, Hegel não se interessou sobre pela preocupação do povo egípcio com a organização do Estado, desde o uso da escrita para a comunicação, para a divulgação das leis, a oratória na participação de diversos grupos nas decisões da sociedade, mostrando que as decisões não se concentravam nas mãos do Faraó; além da existência de um conjunto sofisticado de leis, fazendo valer a instituição do direito. Assim, compreendemos como uma certa realidade egípcia engessada se efetivou a partir de interesses epistêmicos que visavam diferenciar sociedades a partir de hierarquias ${ }^{73}$.

Em diversas obras é possível encontrar a admiração de Aristóteles pelos egípcios (OBENGA, 1993). Na História dos Animais, a preocupação com a manutenção da vida animal, além de perceber o Egito como um laboratório vivo, denotando um certo tipo de mentalidade ecológica por parte dos kemetiano. Já em Econômicos de Aristóteles, nota-se uma observação acerca dos costumes egípcios de mercado e, além disso, a presença da relação grega no comércio egípcio. Por meio da literatura egípcia, é possível ter acesso ao mais alto nível de intelectualidade dos egípcios, penetrando, sobretudo, no campo filosófico e social, onde: “o homem podia dialogar com sua própria alma sobre temas metafísicos”74. Esse mundo inteligível egípcio é observado por Aristóteles, que destaca a sabedoria dos egípcios, ao compreenderem as ideias de múltiplo e uno, elementos cruciais para se pensar em termos de universalização.

Dizemos que os sábios do Egipto já tinham visto com a subtileza da sua imaginação esse mundo inteligível e as formas que se encontram nele e as conheciam de forma correcta, fosse através de um saber adquirido, ou por

\footnotetext{
${ }^{70}$ GARAUDY, O Ocidente é um acidente, p. 14

${ }^{71}$ WEIL, Hegel e o Estado, p. 71.

${ }^{72}$ HEGEL, Filosofia da História, p.184.

${ }^{73}$ No livro de Heródoto, História, as referências à tirania ou ao tirano, a déspota ou despotismo, está fazendo alusão a Grécia, mas quando se refere ao Egito, ao Faraó, se expressa em termos de governante, soberano ou rei.

${ }^{74}$ El-NADOURY; VERCOUTTER, O legado do Egito faraônico, p. 152.
} 
instinto e um saber natural. A prova disso é que quando queriam descrever algo o explicavam com uma sabedoria correcta e sublime ${ }^{75}$.

Essa observação feita por Aristóteles nos remete a Pitágoras que possui, como princípio de sua filosofia, a unidade, o uno e a matemática. Ainda pensando em termos de inteligibilidade, Laêrtios $^{76}$ vai dizer que Platão aprendeu a teoria do inteligível com Pitágoras, o mesmo que viveu anos estudando e aprendendo com os egípcios. De acordo com Aristóteles, "os sábios do Egipto já conheciam essas formas correctamente, e exprimiam-nas sem usar a linguagem, mas por sinais e assim eram os seus livros. A primeira causa criou apenas através da sua essência”77.

Se seguirmos nessa linha metafísica, em A filosofia antes dos gregos, José Nunes Carreira aponta sobre uma ontologia egípcia, que versa sobre o ser, sobre a existência, o movimento, que não devem em nada ao pensamento grego, pois elaboraram seus próprios princípios de identidade, de não-contradição e o pensamento do não-ser. Segundo o autor, entendendo o mundo como uma constante mudança, o egípcio sabe lidar com o não ser enquanto aquilo que não é para determinar a sua existência e seu estar no mundo.

O pensamento egípcio lançou a base mais importante para a criação de uma autêntica ontologia, a saber, os meios linguísticos necessários à formulação de noções filosóficas. Há na língua egípcia dois verbos para "ser”, um dos quais $(\mathrm{w} / \mathrm{n} / \mathrm{)}$ com dois particípios, designando o "ente" e "o que foi”, uma capacidade que o latim não possui. E também na forma finita e fazem afirmações sobre a existência dos seres ${ }^{78}$.

José Nunes Carreira também irá nos apresentar uma compreensão egípcia acerca do tempo, que em termos de eternidade e de infinitude escapariam ao tempo enquanto um período determinado fechado dentro de uma possibilidade passada e futura. Segundo ele, "os egípcios chamavam o tempo oportuno de Tp, que se assemelharia ao kairos grego"79. A alta sofisticação do pensamento egípcio não nos deixa dúvida de que os seus pensadores, filósofos, produziam pensamentos tão complexos quanto os gregos, o que podemos chamar de filosofia. Não precisamos discutir aqui acerca da origem da palavra filosofia, philo/sofia, qualquer um sabe e qualquer dicionário nos remete à sua raiz grega, pois é transmitido sem ser questionado ou problematizado, conhecimento que possuímos de cor, por meio dos ensinamentos da tradição que se conserva até os dias de hoje. Acreditamos que havia

\footnotetext{
${ }^{75}$ ARISTÓTELES, A Teologia de Aristóteles, p. 199.

${ }^{76}$ LAÊRTIOS, Vidas e doutrinas de filósofos ilustres, p. 87.

77 ARISTÓTELES, A Teologia de Aristóteles, p. 55.

${ }^{78}$ CARREIRA, Filosofia antes dos gregos, p. 55.

${ }^{79}$ Ibidem, 1994, p. 65.
} 
um modo característico de filosofia grega. Porém, esses argumentos não são o bastante para determinar que não havia filosofia para além do mundo grego. Nas últimas décadas, diversos pesquisadores africanos, brasileiros, europeus e americanos, retomaram a busca dessa discussão que já havia no passado. Dessas pesquisas resultaram algumas teses que são interessantes para ser discutida.

O filósofo congolês Théophile Obenga traduziu o termo egípcio rekhet para filosofia. Rekhet significa perguntar pela natureza das coisas (khet) baseado no conhecimento acurado (rekhet) e bom (nefer) discernimento (upi). A palavra upi significa “julgar”, "discernir”, o que é "dissecar”. A palavra cognata upet significa "especificação”, “julgamento" e upset quer dizer "específico”, isto é, dar os detalhes de algo ${ }^{80}$. Já Molefi Asante, filósofo afroamericano, usa o termo africano seba, que consta no túmulo de Antef I de 2052 a.C, que significaria sábio. Segundo Asante, a palavra seba transformou-se, em “'Sebo' em copta e 'Sophia' em grego”, o que significaria em ciKam (língua falada no Egito) ${ }^{81}$, o "'estilo de raciocínio do povo'. Era a fonte da raiz 'sophia' na palavra 'filosofia""82.

Diógenes Laêrtios, em Vidas e doutrinas dos filósofos ilustres, aponta a possibilidade de pensarmos uma filosofia egípcia, destacando, sobretudo, que os egípcios possuíam uma concepção de justiça, tal como encontramos em Pthah-hotep, que, em seus Ensinamentos, ensina ao juiz a importância de agir dentro da lei na busca do bem, sendo a imparcialidade uma característica indispensável: "se fores um magistrado de prestígio, encarregado de satisfazer a muita gente, não sejas parcial. Ao falares não pendas para um lado, toma cuidado para que ninguém se queixe: 'O juiz distorce a questão” e tua decisão volte-se contra ti"”s3.

Para os egípcios, Héfaistos era filho do Nilo, e com ele começou a filosofia (...) A filosofia dos egípcios no tocante aos deuses e à justiça é descrita da maneira seguinte. Dizem eles que o primeiro princípio seria a matéria, da qual se derivaram então os quatro elementos e surgiram finalmente todos os seres vivos. (...) Eles também instituíram leis tendo em vista a justiça, atribuindo-as a Hermes, e divinizaram os animais úteis aos homens, além de pretenderem ser os criadores da geometria, da astronomia e da aritmética. São esses os dados referentes à invenção da filosofia ${ }^{84}$.

\footnotetext{
${ }^{80}$ OBENGA, Egypt: Ancient History of African Philosophy, p. 33-34.

${ }^{81}$ Existem várias línguas faladas no Egito Antigo, entre elas o Mdu Ntr, ciKam e o Copta.

${ }^{82}$ ASANTE, Afrocentricidade como Crítica do Paradigma Hegemônico Ocidental: Introdução a uma Ideia, 2014; ASANTE, Uma Origem Africana da filosofia: Mito ou Realidade?, 2016.

${ }^{83}$ PTAH-HOTEP, Ensinamentos de Ptahhotep, p. 254.

${ }^{84}$ LAÊRTIOS, Vidas e doutrinas dos filósofos ilustres, p. 13.
} 
Como vimos, os kemetianos possuíam uma concepção de justiça, que poderia ser regulada por leis divinas ou por leis humanas. Mais uma vez encontramos um elemento que destrói todos os preconceitos acerca do pensamento egípcio, uma vez que os egípcios possuíam uma ideia ou um conceito de justiça que era traduzido na palavra maât. $\mathrm{O}$ conceito de maât pode ser entendido de diversas formas, pois seu uso era variado, desde o nome da deusa até um conceito abstrato regulador da vida social quanto um conceito de justiça limitado ao direito. Portanto, pensar maât enquanto espírito, justiça, bem, são formas que demonstram a capacidade de abstração e reflexão filosófica do povo africano egípcio.

Os antigos egípcios já haviam feito a diferença entre, por um lado, uma justiça geral, cósmica, moral e uma conduta subjetiva de acordo com a Ordem garantida pelo Rei e, por outro lado, a justiça particular, tanto individual como social, no âmbito da lei e do juiz, pela objetividade de uma divisão equitativa de propriedade. (...) "Removendo-me de uma visão" compacta "do maât, tentei mostrar o quanto os antigos egípcios estavam mais conscientes de sua dualidade e tomaram o cuidado de distinguir aspectos de sua natureza dupla "celestial e terrestre", em ritos, em textos, em uma iconografia que são sempre apropriados ${ }^{85}$.

Ainda pela arte, uma teckhne, uma pintura, a organização do ajuntamento da escrita hieroglífica, os egípcios, nesse sentido, a fim de demonstrar sua sofisticação estética na busca de uma simetria perfeita, precisavam inserir imagens e símbolos, dentro de retângulos imaginários, ou seja, era preciso uma sofisticada capacidade de abstração, que estava concentrada nos conhecimentos dos escribas.

Aproximando o pensamento grego do egípcio, Jean-Pierre Faye, aponta que o pensamento de Aristóteles, no início da Metafísica, se dava devido à possibilidade do pensamento matemático que os gregos aprenderam com os egípcios. Assim, diz ele: "O ente se conta de múltiplas maneiras” - to on legetai pollakhos. E isto, de fato, desde o momento em que as tekhnai matemáticas surgem no Egito ${ }^{86}$. Segundo Heródoto, os calendários tal como conhecemos, a organização dos meses e dos anos, além da construção das pirâmides, só foi possível devido ao altíssimo grau de abstração matemática dos egípcios: "todos são unânimes em afirmar que os Egípcios foram os primeiros a estabelecer a noção de ano, dividindo este em doze partes, segundo o conhecimento que possuíam dos astros" ${ }^{87}$.

\footnotetext{
${ }^{85}$ MENU, Maât, ordre social et inégalités dans l'Égypte ancienne, p. 51.

${ }^{86}$ FAYE, Narrativas totalitárias, p. 290

${ }^{87}$ HERÓDOTO, História, p. 135.
} 
No texto Busiris de Isócrates, o filósofo grego defende a ideia de que os egípcios inventaram dois modos distintos para o homem que vive em sociedade, são eles a medicina visando ao cuidado do corpo e a filosofia que possuía como intuito o cuidado da alma. Nesta obra o filósofo grego explica que os egípcios "revelaram a prática da filosofia que pode ao mesmo tempo fixar leis (nomothetesai) e procurar a natureza das coisas (kaì tèn phúsin ton ónton zetêsai dúnatai)" ${ }^{88}$. O que Isócrates está nos dizendo é que havia, no Egito, uma alta preocupação com o lugar do homem no mundo, com o seu modo de ser e de existir. O Egito "é descrito como "o lugar mais belo do universo" e seria o berço da filosofia; seria a origem do "cuidado de si" em Michel Foucault; fundador de práticas que afetam a alma" 9 .

Segundo Heródoto, Platão vivera quase dez anos no Egito e, além de percebermos uma semelhança entre o rei-filósofo e o faraó, podemos encontrar, na teoria da reminiscência, a compreensão egípcia do mundo dos vivos e dos mortos, que pode ser entendida em termos de repetição. Inclusive, na mitologia egípcia, a repetição pode ser entendida também a partir da temporalidade e do estar no mundo, como no caso do mito egípcio que narra o combate diário que sempre se repete de Rá, o deus do sol, com Apep ou Apophis, a grande serpente, que traria o kaos e a desordem, a fim de destruir a vida. Mas o deus sempre mata a serpente, que sempre retorna infinitamente conseguindo, desta maneira, estabelecer a ordem. Entretanto, a grande serpente acaba sempre retornando e o combate se repete infinitamente, como é o caso de duas compreensões de tempo no Egito Antigo: eternidade-djet que é compreendida a partir de sua estaticidade e eternidade-neheh enquanto um aspecto da fluidez ${ }^{90}$. Diante dessa lenda, podemos ver uma luta constante de manutenção da razão, do logos egípcio, para assegurar a ordem, enquanto a serpente traria a desordem social.

Diante de tantos fatos e documentos que comprovam ou que chamam a atenção acerca de um Egito para além daquele limitado, fechado, fraco, obscuro em relação à grande luminosidade grega que nos fori transmitida, só podemos entender que a negação, a ocultação de um Egito rico de saberes, filosófico, complexo e com uma larga história com mudanças e transformações, se deu devido ao racismo epistêmico, que quando não foi negado, vítima de um epistemicídio, foi embranquecido. O filósofo Renato Noguera, aponta esse projeto racista que se deu início na Alemanha, que visava à exaltação da Grécia e ao rebaixamento das sociedades africanas e asiáticas, negando de todas as maneiras influências externas à Grécia.

No modelo antigo de interpretação da história, nota-se a grande influência das culturas africanas e asiáticas, principalmente a egípcia e a fenícia, na

\footnotetext{
${ }^{88}$ BRISSON, Leituras de Platão, p. 207.

${ }^{89}$ MATHIEU, Platon, le Egypte et la question de l'ame, p. 37.

${ }^{90}$ ARAÚJO, Pobres faraós divinos, 2000.
} 
civilização grega. No entanto, como resultado de uma reinterpretação racista da história, o modelo antigo é substituído pelo modelo ariano. (...) Nesta, no seu entender, há «negação sistemática» de qualquer influência africana ou asiática na civilização grega ${ }^{91}$.

Diante do exposto, o retorno ao Egito é uma tarefa de descolonização, para afirmar uma filosofia negra africana, que sofrera ao longo dos séculos a mistificação de filósofos e egiptólogos europeus, como nos lembra Aimé Césaire ${ }^{92}$.

\section{Referências}

AMENEMOPE. Ensinamentos de Amenemope. In. ARAÚJO, Emanuel. Escrito para a eternidade: a literatura no Egito faraônico. Brasília: Editora da Universidade de Brasília: São Paulo: Imprensa Oficial do Estado, 2000.

ARAÚJO, Emanuel, Pobres faraós divinos in. Textos de história, vol. 04, n. 2, 1996.

ARISTÓTELES. A constituição de Atenas. Trad. Edson Bini. São Paulo: Edipro, 2012.

ARISTÓTELES. A Teologia de Aristóteles. Trad. Catarina Belo. Lisboa: Imprensa Nacional Casa da Moeda, 2010.

ARRAIS, Nely Feitoza. Hierarquia e Mobilidade Social no Egito do Reino Novo. In. Semna - Estudos de Egiptologia I. Antonio Brancaglion Jr., Thais Rocha da Silva, Rennan de Souza Lemos, Raizza Teixeira dos Santos (orgs.). - Rio de Janeiro: Seshat - Laboratório de Egiptologia do Museu Nacional, 2014.

ARRAIS, Nely Feitoza. Isis, o trono do Egito: análise das representações da deusa e do poder régio no Egito do Reino Novo. In. Semna - Estudos de Egiptologia IV. Antonio Brancaglion Jr.; Gisela Chapot (orgs.). - Rio de Janeiro: Seshat - Laboratório de Egiptologia do Museu Nacional, 2017.

ASANTE, Molefi Kete. Afrocentricidade como Crítica do Paradigma Hegemônico Ocidental: Introdução a uma Ideia. Trad. Renato Noguera; Marcelo J. D. Moraes; Aline Carmo. In. Revista Ensaios Filosóficos. Vol. 14 - 2016.

ASANTE, Molefi Kete. Uma Origem Africana da filosofia: Mito ou Realidade? Trad. Marcos Carvalho Lopes. In. Capoeira - Revista de Humanidades e Letras. Vol.1. № , 1, 2014.

BAKR, A. Abu. O Egito faraônico. In. MOKHTAR, Gamal. História geral da África: África antiga. Brasília: Vol. 2. UNESCO, 2010.

\footnotetext{
${ }^{91}$ NOGUERA, A ética da serenidade: o caminho da barca e a medida da balança na filosofia de Amenemope, p. 143.

${ }^{92}$ CÉSAIRE, Discurso sobre o colonialismo, 2010.
} 
BRISSON, Luc. Leituras de Platão. Trad. Sônia Maria Maciel. Rio Grande do Sul: EdiPUCRS, 2003.

CARDOSO, Ciro Flamarion. O Egito Antigo. São Paulo: Editora Brasiliense, 1992.

CARREIRA, José Nunes. Filosofia Antes dos Gregos. Mem Martins: Publicações EuropaAmérica, 1994.

CÉSAIRE, Aimé. Discurso sobre o colonialismo. Trad.Anísio Garcez Homem. Florianópolis: Letras Contemporâneas, 2010.

DESCARTES, René. Regras para a direção do espírito. Trad. João Gama. Lisboa: Edições 70, 1985.

DIOP, Cheikh Anta. A unidade cultural da África Negra. Esferas do patriarcado e do matriarcado na antiguidade clássica. Trad. Sílvia Cunha Neto. Luanda: Edições Mulemba, 2014.

DIOP, Cheikh Anta. Civilisation ou Barbarie. Paris: Presence africaine, 1981.

DIOP, Cheikh Anta. Origem dos antigos egípcios. In. MOKHTAR, Gamal. História geral da África: África antiga. Brasília: Vol. 2. UNESCO, 2010.

DETIENNE, Marcel. Os gregos e nós. Trad. Mariana Paolozzi. São Paulo: Edições Loyola, 2014.

DOBERSTEIN, Arnoldo Walter. O Egito Antigo. Porto Alegre: EDIPUCRS, 2010.

DOVE, Nah. Uma Crítica Africano-Centrada à Lógica de Marx. Trad. Wellignton Santos; Fernando Jesus. In. Ensaios Filosóficos. Volume XVI - Dezembro, 2017.

EL-NADOURY, Rashid; VERCOUTTER, J. O legado do Egito faraônico. In. MOKHTAR, Gamal. História geral da África: África antiga. Brasília: Vol. 2. UNESCO, 2010.

FAYE, Jean-Pierre. Narrativas totalitárias. Trad. Paula Martins. São Paulo: Editora 34, 1996.

GARAUDY, Roger. O Ocidente é um acidente. Trad. Virgínia Novais da Mata-Machado. Rio de Janeiro: Editora Forense Universitária, 1983.

GAMA-ROLLAND, Cintia. L'existence ou pas d une "démocratisation" ou "demotisation" du post mortem : l'étude des chaoabtis du Nouvel Empire. In. Estudos de Egiptologia IV. Org. Antonio Brancaglion Jr.; Gisela Chapot. Rio de Janeiro: Editora Klíne, 2017.

HARTOG, François. Memória de Ulisses: narrativas sobre a fronteira na Grécia antiga. Trad. Jacyntho Lins Brandão. Belo Horizonte: UFMG, 2004.

HARRIS, J. R. O legado do Egito. Trad. Henrique de Araújo Mesquita. Rio de Janeiro: Imago, 1993.

HEGEL, G.W. Friedrich. Filosofia da História. Trad. Maria Rodrigues; Hans Harden. Brasília: Editora da UnB, 2008.

HERÓDOTO. História. Trad. Bartolomé Pou. Ed. eBooksBrasil, 2006.

JAEGER, Werner. Paideia. Trad. Artur M. Parreira. São Paulo: Editora WMF Martins Fontes, 2010. 
JAMES, George G. M. Stolen Legacy: Greek Philosophy is Stolen Egyptian Philosophy. The Journal of Pan African Studies 2009 eBook.

JOÃO, Maria Thereza David. Implicações econômicas dos templos egípcios e a constituição de poderes locais: um estudo sobre o Reino Antigo. In. Estudos de Egiptologia IV. Org. Antonio Brancaglion Jr.; Gisela Chapot. Rio de Janeiro: Editora Klíne, 2014.

LAÊRTIOS, Diógenes. Vidas e doutrinas dos filósofos ilustres. Trad. Mario da Gama Kury. Brasília: Ed. UnB, 2008.

MANACORDA, Mario A. História da Educação. Trad. Gaetano Lo Manacorda. São Paulo: Cortez, 2010.

MATHIEU, Frederich. Platon, le Egypte et la question de l'ame. Paris, In Libro Veritas, 2014. MENU, Bernadette. Maât, ordre social et inégalités dans l’Égypte ancienne. In. Droit et cultures [En ligne], 69 | 20151, mis en ligne le 20 avril 2015, consulté le 24 juillet 2016. URL : http://droitcultures.revues.org/3510

MOORE, Carlos. Racismo e Sociedade. Belo Horizonte: Nandyala, 2012.

MORAES, Marcelo. A heterogipcia enquanto o outro egípcio na filosofia. In. Estudos de Egiptologia IV. Org. Antonio Brancaglion Jr.; Gisela Chapot. Rio de Janeiro: Editora Klíne, 2017.

MORAES, Marcelo. A filosofia ética e política do Egito Antigo. . In. Estudos de Egiptologia V. Org. Antonio Brancaglion Jr.; Gisela Chapot. Rio de Janeiro: Editora Klíne, 2018.

NOGUERA, Renato. A ética da serenidade: o caminho da barca e a medida da balança na filosofia de Amenemope. In. Ensaios Filosóficos. Vol. 08, 2013.

NOGUERA, Renato. Amenemope, o coração e a filosofia, ou, a cardiografia (do pensamento). In. BRANCAGLION, Antonio. Semma. Estudo de Egiptologia II. Rio de Janeiro, 2015.

OBENGA, Théophile. Egypt: Ancient History of African Philosophy. In WIREDU, Kwasi. A companion to African Philosophy. Oxford: Blackwell Publishing, 2004.

OBENGA, Théophile. La philosophie africaine de la période pharaonique (2780-330 a. C.). Paris: L’Harmattan, 1990.

OBENGA, Théophile. Aristote et egypte ancienne. ANKH, N² Avril, 1993.

PLATÃo. República. Trad. Maria Helena da Rocha Pereira. Lisboa: Fundação Calouste Gulbbenkian, 2001.

PLATÃO. Timeu-Crítias. Trad. Rodolfo Lopes. Coimbra: Imprensa da Universidade de Coimbra, 2013.

PLUTARCO. Vidas Paralelas. Trad. Ranz Romanillos. Gredos: Madrid, 2001. 
PTAHHOTEP. Ensinamentos de Ptahhotep. In. ARAÚJO, Emanuel. Escrito para a eternidade: a literatura no Egito faraônico. Brasília: Editora da Universidade de Brasília: São Paulo: Imprensa Oficial do Estado, 2000.

RAMOSE, Mogobe. Sobre a Legitimidade e o Estudo da Filosofia Africana. Trad. Dirce Solis. In Revista Ensaios Filosóficos. Vol. 04, 2011.

SCHURÉ, Édouard. Pitágoras. São Paulo: Martin Claret, 1986.

VERCoUtTer, Jean. O Egito Antigo. Trad. Francisco G. Heidemann. São Paulo: Difel, 1980.

VERNANT, Jean-Pierre. As origens do pensamento grego. Trad. Ísis Borges. Rio de Janeiro: Difel, 2004.

YOYOTTE, J. O Egito faraônico: sociedade, economia e cultura. In. MOKHTAR, Gamal. História geral da África: África antiga. Brasília: Vol. 2. UNESCO, 2010.

WEIL, Eric. Hegel e o Estado. Trad. Carlos Nougué. Realizações Editora, São Paulo, 2011. 